Glanz, Susan. "Szentkirályi, Endre. 2014. Cold War to Warm Cooperation - The Military Service of Cleveland Hungarians. Egy amerikai város magyar katonái, 1950-2014 (English and Hungarian). Budapest: Zrinyi Kiadó. 290 pp." Hungarian Cultural Studies. e-Journal of the American Hungarian Educators Association, Volume 8 (2015): http://ahea.pitt.edu DOI: 10.5195/ahea.2015.196

\title{
Szentkirályi, Endre. 2014. Cold War to Warm Cooperation - The Military Service of Cleveland Hungarians. Egy amerikai város magyar katonái, 1950-2014 (English and Hungarian). Budapest: Zrinyi Kiadó. $290 \mathrm{pp}$.
}

\section{Reviewed by Susan Glanz, St. John's University}

Endre Szentkirályi, a Cleveland educator, is a proud second-generation HungarianAmerican. His pride in the achievements of other Hungarian-Americans of several generations shines throughout his new book, which is based on oral history accounts of Cleveland Hungarian-Americans telling about their military service in the United States army since 1950 to the present. This book is a revised and updated part of Szentkirályi's 2013 Ph.D. dissertation written at the University of Debrecen's Doctoral School of Literary Studies and supervised by Tibor Glant. To be included in this book the individuals had to have been participants in one of Cleveland's Hungarian organizations such as church congregations, scouts or dance groups. Szentkirályi's method of gathering information about the Hungarian-Americans who served in the US army as of 1950, wherein the participants themselves recruit other informants from their community, is often called "snowball" or "bring a friend." This method yielded some 330 names, of which over 250 individuals or their family members consented to be interviewed for the book. Some of the interviews were conducted face to face, while others were completed over the telephone or in email exchanges.

The book is divided into three parts. Part One is in English and includes an introductory chapter on the method used for the data collection as well as an analysis of the sources of motivation for Hungarian-Americans join the military. There are four additional chapters in this part grouped by the kind of military service of the interviewees, the historical period and the wars in which they served. The chapter about the years 1950-1964 covers the activities of those who served in the Korean War as well as at various bases worldwide. The chapter on 1965-1975 is about those who served in the Vietnam War; whereas those who volunteered between the years 1976-1989 -- as by that time army service in the US became non-obligatory -- served at various posts both within the US and around the world. While many of those who served in the first two periods (1950-1964 and 1965-1975) were American born, several other individuals of those periods joined the military to take advantage of the Hodge Act, which allowed refugee immigrants to earn American citizenship after five years of service in the US military. This entire part ends with a brief chapter on the service of those military personnel who served in the last fifteen years. All in all, Szentkirályi's book presents interviews with forty officers, including two generals and several colonels, as well as many sets of brothers or family lineages of US army men and women. While only two of the interviewees are female, several men do mention their sisters, daughters or other female relatives who serve/d in the US military.

$(\mathrm{cc}) \mathrm{BY}$

ULIS D-Serle
New articles in this journal are licensed under a Creative Commons Attribution 4.0 International License.

This journal is published by the University Library System of the University of Pittsburgh as part of its D-Scribe Digital Publishing Program and is cosponsored by the University of Pittsburgh Press 
Glanz, Susan. "Szentkirályi, Endre. 2014. Cold War to Warm Cooperation - The Military Service of Cleveland Hungarians. Egy amerikai város magyar katonái, 1950-2014 (English and Hungarian). Budapest: Zrinyi Kiadó. 290 pp." Hungarian Cultural Studies. e-Journal of the American Hungarian Educators Association, Volume 8 (2015): http://ahea.pitt.edu DOI: 10.5195/ahea.2015.196

Part Two, at 141 pages, is the longest in the book and consists of well-reproduced photographs and other documents contributed by the interviewees or their families. Part Three of the book is written in Hungarian and offers a condensed explanation and summary of the purpose of the book and of its methodology, and in it the lives and service of over 250 HungarianAmericans is presented in alphabetical order, as opposed to the periodical division presented in the English language Part One. Interestingly, two individuals who served in the Peace Corps (non-military independent agency founded by President John F. Kennedy in 1961 to promote worldwide peace and friendship) are included only in the Hungarian-language section. In reading these abbreviated biographies one wishes to have been present at the oral interviews and ask some of the interviewees for more detail about their exploits, as sometimes their accounts read as somewhat laconic. Two examples for this wish to hear and learn more are: Attila Farkas who, just before escaping to the US in 1956, served in a Hungarian armored troop that freed Cardinal József Mindszenty from the Hungarian prison; Mátyás Zsolnay who, while serving in the US army in the 1960s, was in fact an American CIA plant in Hungary. Szentkirályi's book includes a very useful chart that compares the various ranks in the US armed forces with their NATO and Hungarian equivalents. In addition, the names of all servicemen and women included in this book as well as some excerpts from it can also be found on the website of the Cleveland Hungarian Museum, at: http://clevelandhungarianmuseum.org/cleveland-hungarians-whoserved-in-the-us-military-1950-2014/

Szentkirályi's book is an important addition to the very few publications about the military service of Hungarian émigrés in America such as, for example: Eugene Pivány's Hungarians in the American Civil War (Cleveland Print House, 1913); István Kornél Vida's Hungarian Émigrés in the American Civil War: A History and Biographical Dictionary (Jefferson, NC: McFarland, 2012; reviewed in Hungarian Cultural Studies 5 (2012), at: http://ahea.pitt.edu/ojs/index.php/ahea/article/view/98/85); and Ilona Kovács's Katonalevelek Az amerikai magyarok második generációja az amerikai hadseregben a második világháború idején 1942-1945 / Soldier Letters - Second Generation American Hungarian Soldiers in the US Army during World War II, 1942-1945 (Budapest: Néprajzi Múzeum, 2012; reviewed in Hungarian Cultural Studies 6 (2013) at: http://ahea.net/sitefiles/file/journals/201311/rosenkatonalevelekproofedOct15.pdf

Endre Szentkirályi is the right person to have undertaken the mission of memorializing the military service of Hungarian-Americans as he has close family members serving in the US army, like his brother, Colonel Zsolt Szentkirályi, and cousin, lawyer Major Ildikó Szentkirályi, as well as several friends who have served or are currently serving in the military. Some of those whose narratives are recorded in this book have with time moved away from Cleveland and some have already died, but the common message emphasized by all interviewees is that they served America with dignity and pride. 